\title{
Journal of

\section{Is diatom size selection by harpacticoid copepods related to grazer body size?}

\author{
Marleen De Troch ${ }^{\mathrm{a}, *}$, Victor Chepurnov ${ }^{\mathrm{b}}$, Hendrik Gheerardyn ${ }^{\mathrm{a}}$, \\ Ann Vanreusel ${ }^{\mathrm{a}}$, Emil Ólafsson ${ }^{\mathrm{c}}$ \\ ${ }^{a}$ Ghent University, Biology Department, Marine Biology Section, Campus Sterre, Krijgslaan 281, S8, B-9000 Gent, Belgium \\ ${ }^{\mathrm{b}}$ Ghent University, Biology Department, Protistology and Aquatic Ecology, Campus Sterre, Krijgslaan 281, S8, B-9000 Gent, Belgium \\ c Stockholm University, Department of Zoology, SE-10691 Stockholm, Sweden
}

Received 18 July 2005; received in revised form 25 October 2005; accepted 26 October 2005

\begin{abstract}
Copepods are known as important consumers of primary production and are eaten by larger animals. They therefore form a main link to higher trophic levels. While feeding pathways and specificity of planktonic copepods have been well studied, the selectivity of the benthic harpacticoid copepods is far less documented. A better knowledge of the functional ecology of harpacticoids as important grazers on primary producers may have consequences for the re-evaluation of basic energy flow in benthic ecosystems.

We tested whether size selectivity for diatoms exists in harpacticoid copepods. We hypothesized that size selectivity of harpacticoid copepod species is strongly related to body size. Because of morphological constraints, we expected smaller copepods to prefer smaller diatoms while larger copepods should be able to consume both small and large diatoms. We tested this hypothesis in four harpacticoid copepod species of varied body size: Tigriopus brevicornis, Harpacticus obscurus, Amphiascus minutus and Paramphiascella fulvofasciata. As food source we used two ${ }^{13} \mathrm{C}$ labelled strains of the benthic diatom Seminavis robusta with a four-fold difference in cell biovolume.

Three out of four harpacticoid species showed size selectivity: H. obscurus and A. minutus preferred the larger Seminavis cells, while P. fulvofasciata selected the smaller Seminavis cells. Based on monoclonal treatments, there was no clear preference found for T. brevicornis although there was a small preference for large cells in the mixed treatments. Except for P. fulvofasciata, all species showed a lower uptake when offered the mixed diet (both small and large cells). Although most species showed a size selectivity, our results suggest that this selectivity was not related to their body size. However, the only species that ate significantly more of small diatoms was characterised by comparatively small mouthparts in relation to its body size.
\end{abstract}

(C) 2005 Elsevier B.V. All rights reserved.

Keywords: Copepoda; Diatoms; Grazing; Selection

\section{Introduction}

Harpacticoid copepods are known to consume a wide spectrum of food sources that includes microalgae

\footnotetext{
* Corresponding author. Tel.: +32 926485 20; fax: +32 92648598.

E-mail address: marleen.detroch@UGent.be (M. De Troch).
}

(Carman and Thistle, 1985; Rieper, 1985; Decho, 1988), protozoans (Rieper and Flotow, 1981), bacteria (Rieper, 1978, 1982), organic detritus (Rudnick, 1989; Rieper-Kirchner et al., 1991) and even flesh (Lopez, 1982; Guidi, 1984; Seifried and Durbaum, 2000) and play a significant role in the transfer of energy from primary producers to top trophic levels in aquatic food 
webs (e.g. Sogard, 1984; De Troch et al., 1998; BuffanDubau and Carman, 2000). Copepods are either directly consumed by top predators (e.g. Gee, 1989; De Troch et al., 1998; Turner, 2004; Gorokhova et al., 2005) or linked to them through the food-web (e.g. HaroGaray, 2003). From such a diverse resource pool, one can wonder if consumers indiscriminately gather particles as they encounter food or selectively ingest according to specific nutritional values. The results of studies of pelagic copepods (mainly Calanoida) illustrate they are able to select the ingested food particles both by sizes (e.g. Sommer et al., 2000) and chemical properties ('taste', DeMott, 1988).

In general, the size selection is also related to handling time and energy costs involved in searching for food. Classical optimal foraging theory (OFT; Stephens and Krebs, 1986) predicts that individuals should feed exclusively from the most profitable resource as long as that resource is in sufficient supply. From this one would expect that species adopt feeding modes that generate the highest energy intake rate, i.e. that prey selection changes according to the relative concentrations of alternative prey (e.g. Kiorboe et al., 1996; Cruz-Rivera and Hay, 2000). For example, the planktonic copepod Acartia tonsa spends disproportionately more time in the feeding mode (suspension feeding or ambush feeding) that provides the greatest reward (Kiorboe et al., 1996). However, the possibility to consume certain food items (e.g. larger ones) may not only depend on prey availability but also upon morphological constraints such as the size and functionality of mouthparts of the grazer. Furthermore, the degree of digestion and the survival of gut passage by some food particles are factors that can also influence food-grazer interactions, although this aspect of assimilation has been relatively neglected (Porter, 1973; Moore, 1975; Underwood and Thomas, 1990). In nature, however, the efficiency with which an organism utilizes a certain food source does not only depend on the ability of the consumer to digest the material but also on the specific food available and its abundance (Hicks and Coull, 1983; unpubl. data).

At present, most of our knowledge on food selectivity of copepods results from pelagic systems (e.g. DeMott, 1989; Irigoien et al., 2000; Sommer et al., 2000; Tackx et al., 2003) while the benthic counterpart, mainly represented by harpacticoid copepods, remains less documented. Although a better understanding of food selectivity of harpacticoids as important grazers on primary producers may have consequences for the re-evaluation of basic energy flow in benthic ecosystems.
Vanden Berghe and Bergmans (1981) tested three Tisbe species for differential food utilization and found a clear preference for bacteria by Tisbe furcata while two sibling species showed a generalised or indiscriminate selectivity. Rieper (1982) showed that Tisbe holothuriae could even discriminate for specific strains of Gram-negative bacteria. Carman and Thistle (1985) found that three co-occurring benthic copepod species fed on different microbial food sources in their natural environment. Decho and Castenholz (1986) found that Mesochra lilljeborgi fed on phototrophic purple bacteria and selectively assimilated these bacteria. Canuella perplexa, however, preferred microalgae and cyanobacteria to phototrophic purple bacteria (Buffan-Dubau et al., 1996). The results of later studies have supported these findings showing a great variability in food selection by harpacticoid copepods (e.g. Pace and Carman, 1996; Buffan-Dubau and Carman, 2000). More recently, Fechter et al. (2004) inferred that two interstitial harpacticoids were able to locate food by sensing water-borne cues.

Here, we specifically addressed selectivity of four harpacticoid copepods in terms of food particle size. Feeding experiments were conducted with ${ }^{13} \mathrm{C}$ labelled strains of a single benthic diatom species of different cell size. The advantage of using only one species as food is that confounding factors of taste, toxic chemicals, or other structural or chemical properties are removed in the design. Tigriopus brevicornis, Paramphiascella fulvofasciata, Harpacticus obscurus and Amphiascus minutus were selected as grazers because of their different body sizes. Parallel to this experiment, we also studied the mouthparts of these copepods as little or no information on functional morphology is available so far.

\section{Materials and methods}

\subsection{Laboratory conditions and labelling technique}

Four intertidal harpacticoid copepod species were isolated from natural samples: T. brevicornis (family Harpacticidae, southwest coast of Iceland), H. obscurus (family Harpacticidae, north-coast of France, brown alga Fucus serratus), A. minutus (family Diosaccidae, north-coast of France, brown alga $F$. serratus) and $P$. fulvofasciata (family Diosaccidae, Germany, intertidal mudflat). In the laboratory, the copepods were maintained in $1 \mathrm{~L}$ glass beakers, with artificial seawater (c. 32 psu, Instant Ocean ${ }^{\circledR}$ salt, Aquarium Systems, France) and regularly provided with a mixture of benthic diatom 
cultures (Navicula phyllepta, Seminavis robusta and Cylindrotheca closterium).

Two strains of the marine pennate diatom S. robusta were used in the present investigation (Fig. 1). Previously, a series of principal biological attributes of this species (life cycle, sexual reproduction and mating system) has been studied in culture (Chepurnov et al., 2002) underpinning its usage as an appropriate diatom 'model' for various experiments. Both of the clones were obtained experimentally, and they represented a single lineage derived from a cross ( $S$. robusta is heterothallic) of two natural clones (68 and 88 in Chepurnov et al., 2002). The clones were started from single initial cells (each c. $65 \mu \mathrm{m}$ in length), which resulted from sexual reproduction. As typical for most diatoms, vegetative multiplication of Seminavis cells was accompanied by gradual cells size reduction, according to the MacDonald-Pfitzer rule (e.g. Chepurnov et al., 2004). One of the clones (referred to as 'small' elsewhere in the text; voucher designation Sem-F1-6 in our diatom culture collection) was established on November 12, 2001 and by the time the present study began (October 22, 2004), the cells decreased in size to $22.2 \mu \mathrm{m}$ on average (S.D. $=1.22$; range $=20.1-24.5 \mu \mathrm{m} ; N=15)$. The other clone was isolated 3.5 years later (referred to as 'large'; voucher Sem-F2-35A) and the cells were measured to be 59.7 $\mu \mathrm{m}$ long (S.D. $=1.13$; range $=58.4-61.8 \mu \mathrm{m} ; N=15$ ) just before the experiment was set. The clones were reported to be of the same mating type and hence no auxosporulation and cell enlargement occurred when they were grown together in a mixed culture. Biovolume of the cells was calculated as recommended for Seminavis in Hillebrand et al. (1999): average values were 1980 (small clone) and 8280 (large clone) $\mu \mathrm{m}^{3}$. F2 culture medium (Guillard, 1975) based on filtered and sterilized seawater (c. $30 \mathrm{psu}$ ) from the North Sea was used to maintain the diatom cultures.

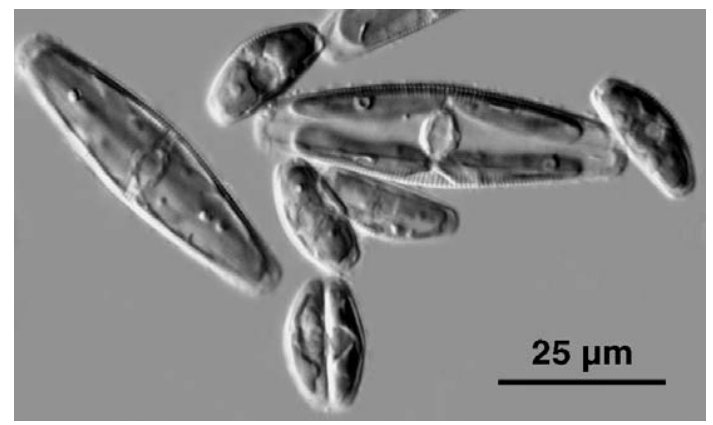

Fig. 1. Seminavis robusta: mixed culture of two different-sized clones which were used in the present study.
For labelling the diatom cells with ${ }^{13} \mathrm{C}, 5 \mathrm{ml}$ of a solution which contained $\mathrm{NaH}^{13} \mathrm{CO}_{3}(336 \mathrm{mg}$ in $100 \mathrm{ml}$ milliQ $\mathrm{H}_{2} \mathrm{O}$ ) was added per $100 \mathrm{ml}$ of the culture medium. Diatoms underwent several subsequent cell divisions in order to reach high densities of cells and high levels of labelling. This labelling technique resulted in an increase in $\delta^{13} \mathrm{C}$ from $-5 \%$ to $85,000 \%$ for the small cells and from $-2 \%$ to $50,000 \%$ for the large cells (see further standardisation of the data). Prior to the experiment, the labelled medium was replaced by artificial seawater.

Single specimens of copepods were picked up by micropipette from the original stock cultures and placed into Petri dishes containing the artificial sea water where they were starved of food. After $24 \mathrm{~h}$, the copepods of single species were transferred into polystyrene $50-\mathrm{mm}$ Petri dishes, with artificial seawater $(15 \mathrm{ml})$ and labelled diatoms for $96 \mathrm{~h}$. To detect ${ }^{13} \mathrm{C} /{ }^{12} \mathrm{C}$ ratios in the tissue of the harpacticoids, a minimum of $15 \mu \mathrm{g} \mathrm{C}$ per species was analysed corresponding to 8,20,20 and 40 adults of T. brevicornis, $H$. obscurus, $P$. fulvofasciata and $A$. minutus in a Petri-plate, respectively. This resulted into 4 petriplates per replicate of a treatment, i.e. one dish for each copepod species.

The cultures were kept and the experiments were performed at $17 \pm 1{ }^{\circ} \mathrm{C}$ and with $12: 12 \mathrm{~h}$ light-dark cycle.

\subsection{Experimental design}

To test whether the copepods can graze the diatoms selectively making a choice among the cells of different sizes, four treatments were performed:

(1) $\mathrm{S}^{*}$ : a total of $4 \times 10^{6}$ cells of small diatom clone, labelled

(2) $\mathrm{L}^{*}$ : a total of $1 \times 10^{6}$ cells of large clone, labelled

(3) $\mathrm{S} * \mathrm{~L}$ : a total of $4 \times 10^{6}$ cells of small clone (labelled) and $1 \times 10^{6}$ of large clone (unlabelled)

(4) SL*: a total of $4 \times 10^{6}$ cells of small clone (unlabelled) and $1 \times 10^{6}$ cells of large clone (labelled).

To estimate the density of diatom cells in cultures, the cells were homogeneously suspended by shaking and then $50 \mu \mathrm{l}$ of the cell suspension was transferred into a well of a multidish (96 wells). In a few hours, after all the cells confidently settled to the bottom of the well, their number was counted under a Zeiss Axiovert 135 inverted microscope (Zeiss Gruppe, Jena, Germany); the values obtained have allowed to estimate the densities in the experimental vessels. 
Control treatments consisted of the natural ${ }^{13} \mathrm{C}$ signature of copepods that came from the original stock culture and were starved for $24 \mathrm{~h}$. They had not been feeding on the labelled diatoms but on a mixture of unlabelled food and as such they are typically depleted in the ${ }^{13} \mathrm{C}$ stable isotope.

Since the biovolume of cells in the large diatom strain was about 4 times higher compared to the small clone (see above), proportionally less number of large cells was used in the treatments to equalize biomasses of the different diatom clones. The mixture of diatom strains $\left(\mathrm{S}^{*} \mathrm{~L}\right.$ and $\left.\mathrm{SL}^{*}\right)$ contained twice as much cell biomass if compared with the monoclonal cultures ( $\mathrm{S}^{*}$ and $\mathrm{L}^{*}$ ). Diatoms were offered in excess densities (i.e. more than what the copepods were likely to consume, see De Troch et al., 2005). Diatom growth in the experimental containers was negligible as the feeding experiments were conducted in artificial seawater (without silica) and growth rate was very low compared to the growth noted when kept in $\mathrm{f} 2$ medium (De Troch, pers. observ.).

Altogether 46 experimental units were used permitting the four treatments, each in triplicate, except treatments $\mathrm{L}^{*}$ and $\mathrm{SL}^{*}$ for $H$. obscurus where only 2 replicates were included due to limited number of copepods available. All experimental units (Petriplates) were placed randomly on a tray in a climate room. The uptake of labelled diatoms by copepods was analysed after $96 \mathrm{~h}$ of grazing.

\subsection{Analytic techniques and data treatment}

At the end of the experiment (after $96 \mathrm{~h}$ ), faecal pellets were collected from both monoclonal treatments and from the biclonal treatment with a microneedle. They were transferred to glass slides, were covered by a cover slip and thus slightly squashed. Observations were made with a standard light microscope (Leitz Diaplan, Wetzlar, Germany) connected to a digital camera (Olympus DP10, Melville, USA).

Subsequently, experimental units containing the copepods were frozen and stored for further analysis. Afterwards, the specimens were sorted manually, washed several times in deionised water and transferred by a microneedle into tin capsules $(8 \times 5 \mathrm{~mm}$, Elemental Microanalysis Limited). The samples were then desiccated in an oven at $60{ }^{\circ} \mathrm{C}$ for $12 \mathrm{~h}$. Measurements of $\delta^{13} \mathrm{C}$ values and copepod biomass (total carbon) were made using an isotope ratio mass spectrometer (type Europa Integra) at the UC Davis Stable Isotope Facility (University of California, USA).
The values of $\delta^{13} \mathrm{C}$ were standardised per individual copepod (total carbon) and per unit carbon of copepod as recommended by Middelburg et al. (2000): incorporation of ${ }^{13} \mathrm{C}$ is reflected as excess (above background) ${ }^{13} \mathrm{C}$, expressed as total uptake (I) in milligrams of ${ }^{13} \mathrm{C}$ per individual and calculated as the product of excess ${ }^{13} \mathrm{C}(\mathrm{E})$ and individual biomass (organic carbon). Excess ${ }^{13} \mathrm{C}$ is the difference between the fraction ${ }^{13} \mathrm{C}$ of the control ( $F_{\text {control }}$, i.e. based on the natural signature of copepods that did not feed on labelled diatoms) and the sample $\left(F_{\text {sample }}\right)$, where $F={ }^{13} \mathrm{C} /\left({ }^{13} \mathrm{C}+{ }^{13} \mathrm{C}\right)=R /(R+1)$. The carbon isotope ratio $(R)$ was derived from the measured $\delta^{13} \mathrm{C}$ values as $R=\left(\delta^{13} \mathrm{C} / 1000+1\right) \times R_{\mathrm{VPDB}}$ with $R_{\mathrm{VPDB}}=0.0112372$ as $\delta^{13} \mathrm{C}$ is expressed relative to Vienna Pee Dee Belemnite (VPDB).

Since the labeled diatoms had different initial $\delta^{13} \mathrm{C}$ signatures (see before), the uptake per individual and uptake per unit carbon of copepod were further standardized taking into account the proportion of ${ }^{13} \mathrm{C}$ in each diatom food source. The amount of diatom carbon that was taken up by copepods and expressed both per individual and per unit carbon of copepod was calculated by multiplying with a factor derived from the atomic percentage ${ }^{13} \mathrm{C}$ of the diatom food source.

Differences in diatom uptake by copepods among the various treatments were tested with one-way and two-way analyses of variance (ANOVA) with Statistica 6.0 software (StatSoft Inc., 2001). A posteriori comparisons were carried out with the Tukey test using 95\% confidence limits. Prior to the ANOVA, the Cochran's $C$-test was used to check the assumption of homoscedasticity.

Mouthparts' morphology of the copepods used in the experiments was studied by detailed morphological observations. For each copepod species, some individuals from the stock culture were dissected with two dissecting needles (tungsten wire, $2.2 \mathrm{~mm}$ diameter, projecting about $2-3 \mathrm{~cm}$ from a holder) under a Wild M5 binocular. Observations and drawings of dissected mouthparts mounted in glycerine were made using a light microscope (Leica DM LS) equipped with a drawing tube.

\section{Results}

\subsection{Stable isotope signatures}

Three of the four harpacticoid species (H. obscurus, A. minutus, P. fulvofasciata) exhibited a significant difference in $\delta^{13} \mathrm{C}$ enrichment (Fig. 2A) while maintained in monoclonal diatom cultures ( $\mathrm{S}^{*}$ or $\mathrm{L}^{*}$ ). Except for $H$. obscurus (see $t$-test) ANOVA tests were allowed based 

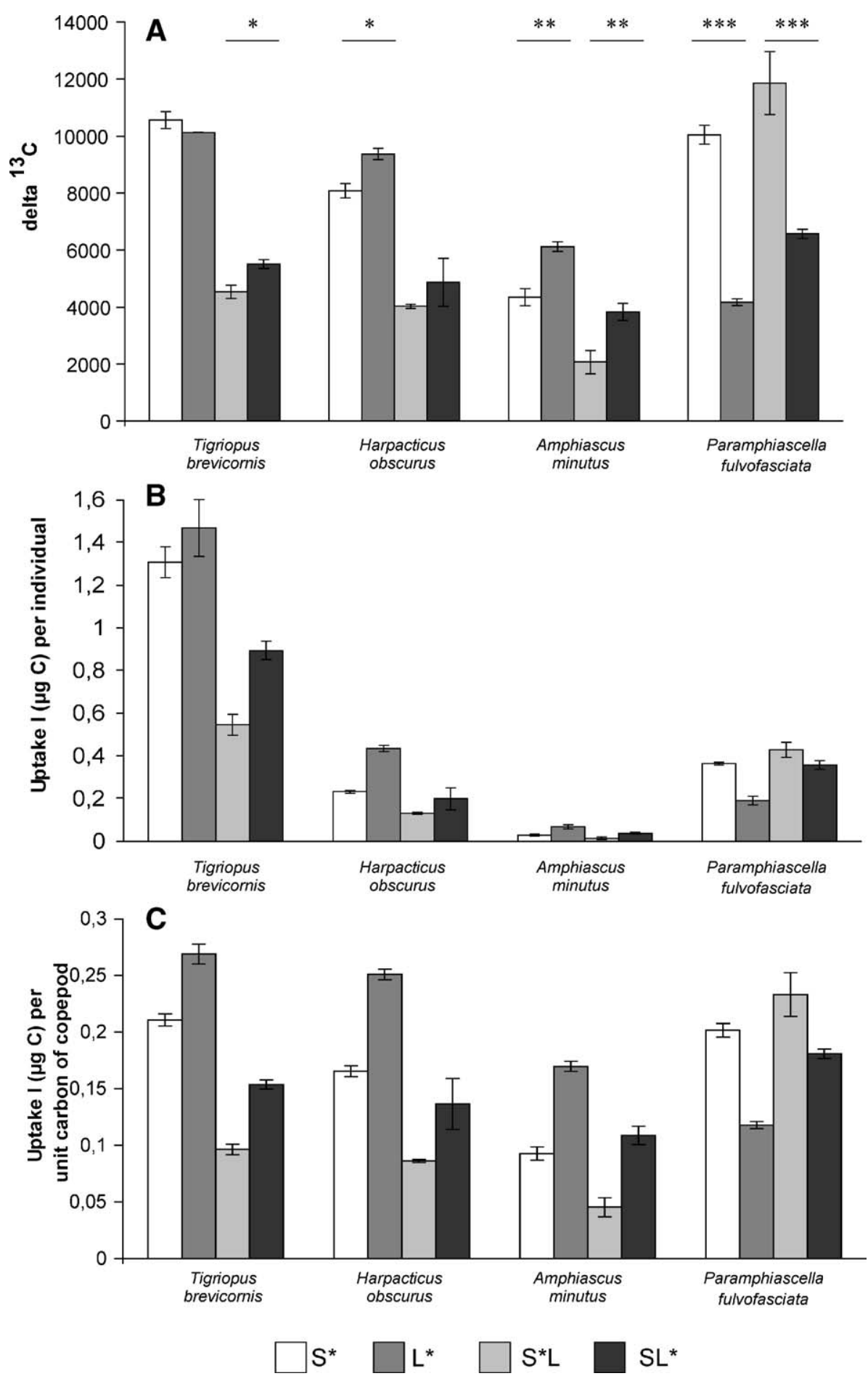

Fig. 2. Diatom uptake (mean \pm standard error) by four harpacticoid copepod species for the different treatments $(\mathrm{S}=\mathrm{small}, \mathrm{L}=$ large diatom cells) expressed as (A) delta ${ }^{13} \mathrm{C}$, (B) total uptake per individual relative to individual biomass, and (C) total uptake per unit carbon of copepod. (significant differences within monoclonal treatments and within the mixed diet indicated by $*=p<0.05, * *=p<0.01, * * *=p<0.001$ ).

on the outcome of the Cochran's $C$-test. A small but statistically significant preference for large diatom cells was found to occur in $H$. obscurus $(t$-test, $p<0.1)$ and more significantly in A. minutus (one-way ANOVA, $p<0.01$ ). In contrast, $P$. fulvofasciata took up significantly more small cells since both the monoclonal dia- 
tom treatments were significantly differed in $\delta^{13} \mathrm{C}$ enrichment (one-way ANOVA, $p<0.001$, Fig. 2A).

In the mixed diet $\left(\mathrm{S}^{*} \mathrm{~L}\right.$ and $\left.\mathrm{SL}^{*}\right), T$. brevicornis (one-way ANOVA, $p<0.05$ ) and A. minutus (one-way ANOVA, $p<0.05$ ) incorporated more ${ }^{13} \mathrm{C}$ from the large cells. P. fulvofasciata was the only species which showed a clear preference for the small cells in the combined treatments: $\delta{ }^{13} \mathrm{C}$ in the $\mathrm{SL}^{*}$ treatment was only half the signal from the $\mathrm{S}^{*} \mathrm{~L}$ treatment (one-way ANOVA, $p<0.01$ ).

In terms of biomass uptake of the labelled diatoms (Fig. 2B), in all the treatments, the largest copepod (i.e. T. brevicornis) took the highest amount while the smallest copepod (i.e. A. minutus) took the smallest amount. In the mixed diet, the biomass dropped to about half that of the monoclonal diet for all species except $P$. fulvofasciata. Both in monoclonal and mixed diet, a similar biomass of small Seminavis cells was taken by P. fulvofasciata irrespective of the presence of large cells.

The values after standardisation per unit carbon of copepod (Fig. 2C) showed the same trend as the $\delta^{13} \mathrm{C}$ values (Fig. 2A). The relatively lower enrichment of the larger cells (see Materials and methods) was reflected in a relatively higher carbon uptake by copepods.

\subsection{Faecal pellets}

In all the treatments, faecal pellets of copepods represented packed remains of diatoms' siliceous exoskeleton, the frustule (Fig. 3). In mixed diets, cells of

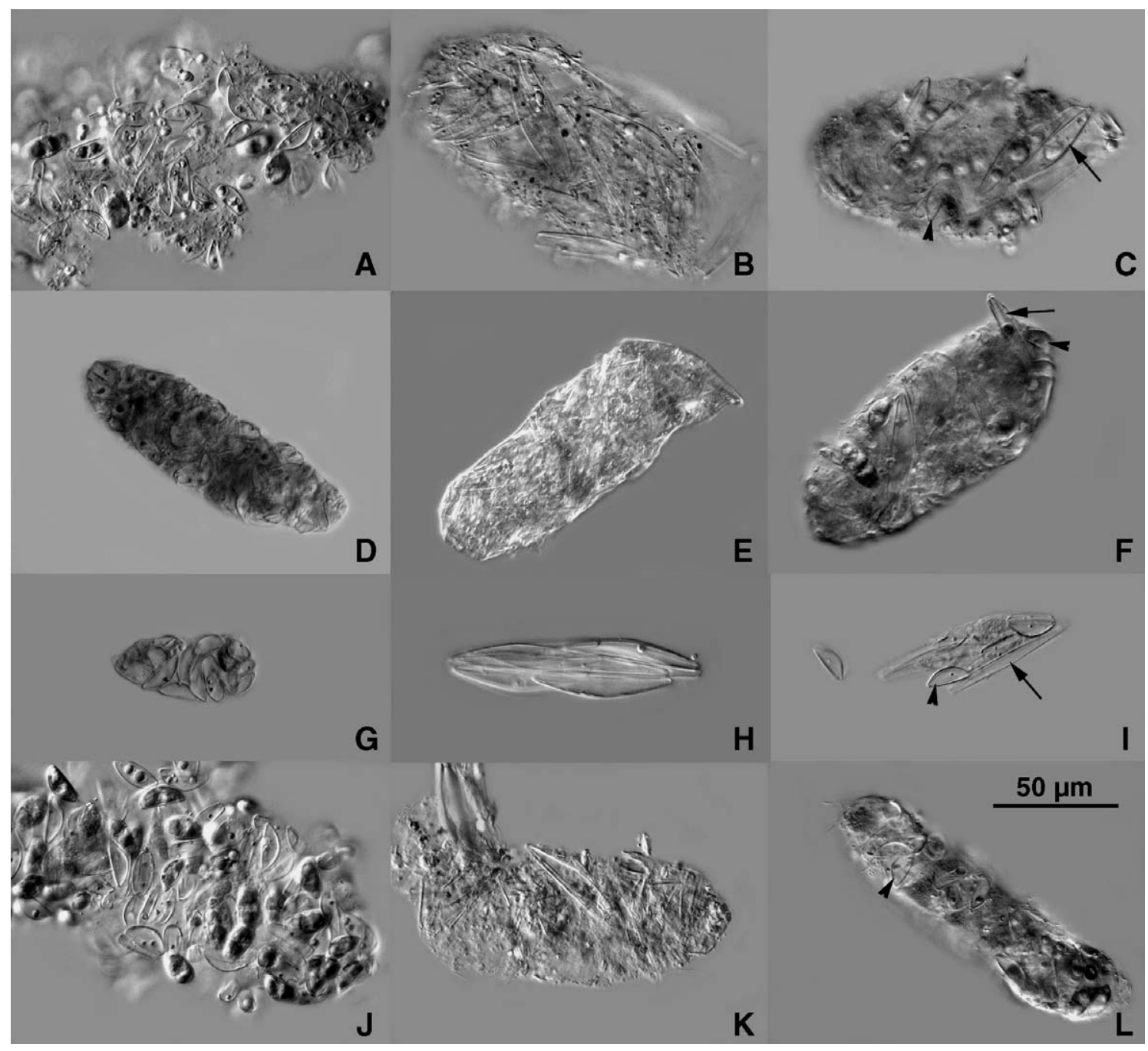

Fig. 3. Faecal pellets of Tigriopus brevicornis (A-C), Harpacticus obscurus (D-F), Amphiascus minutus (G-I) and Paramphiascella fulvofasciata (J-L) fed in cultures of Seminavis robusta: clone 'small' (A, D, G, J), clone 'large' (B, E, H, K) and a mixture of the two clones (C, F, I, L) with indication of small (arrowhead) and large diatom cells (arrow). 
both size classes could be identified in the mass excreted (see arrows and arrowheads in Fig. 3C, F, I), except for P. fulvofasciata (Fig. 3L, see further). Other moreor-less structured fragments observed in the faecal pellets were spherical particles, colourless or brownishpigmented, which most likely represented non-digested protoplast of diatom cells.

The frustules of the small clone were always intact in the faecal pellets of all the copepod species.
Intact and broken frustules of the large diatom clone were also found in the faeces of all copepods, but in the faecal pellets of $A$. minutus the frustules were always intact (Fig. 3H, I). In contrast, large diatom cells in faecal pellets of $H$. obscurus (Fig. 3E) and $P$. fulvofasciata (Fig. 3K) were found predominantly crushed, sometimes into small fragments. Moreover, no large cells could be recognised as such in the faecal pellets of $P$. fulvofasciata from the mixed diet
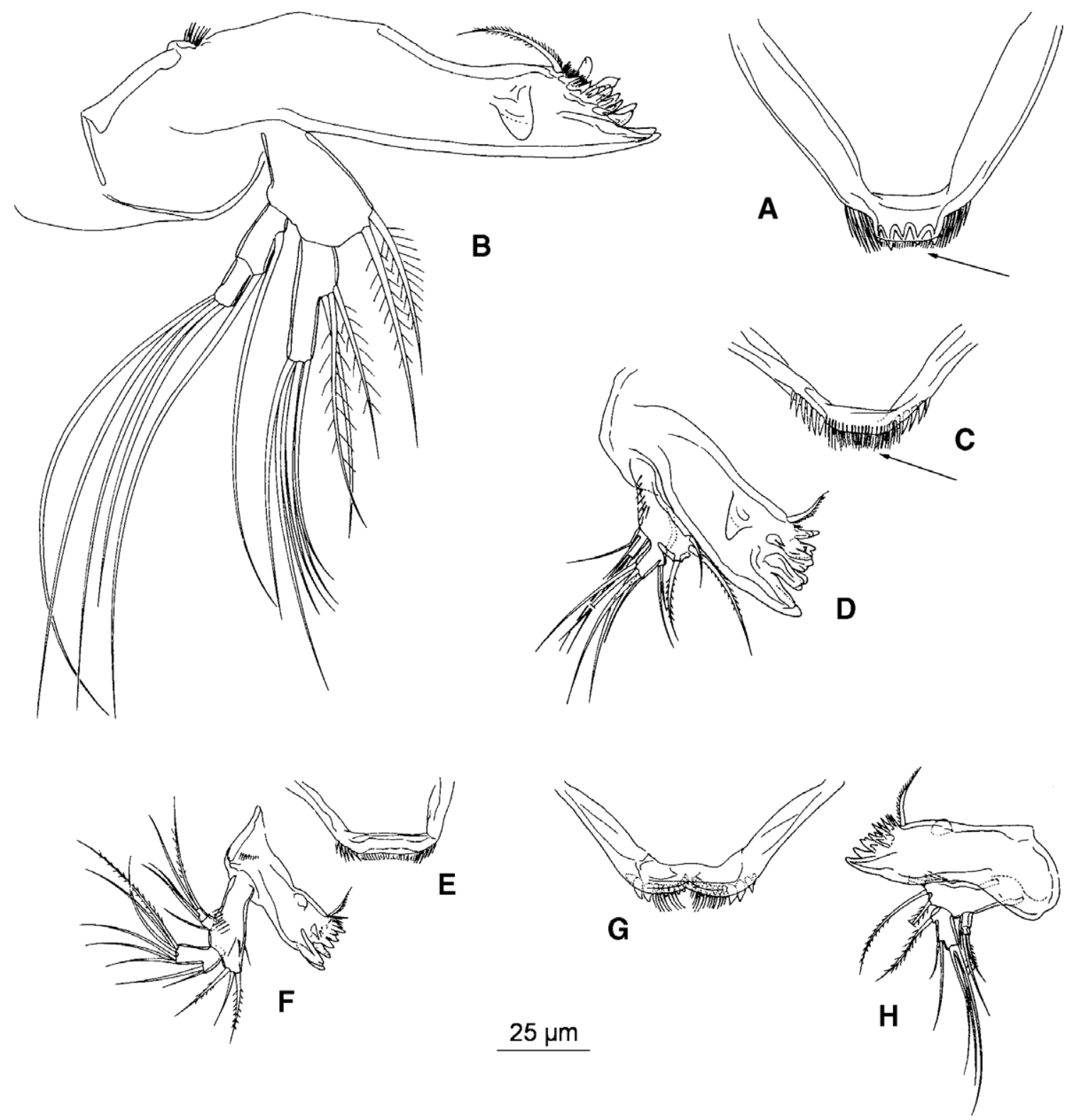

Fig. 4. Labrum and right mandible of Tigriopus brevicornis (A-B), Harpacticus obscurus (C-D), Amphiascus minutus (E-F) and Paramphiascella fulvofasciata $(\mathrm{G}-\mathrm{H}$ : posterior view). Arrows indicate specific structure of the labrum (see text). Drawings by $\mathrm{H}$. Gheerardyn. 
treatments (see Fig. 3L). Finally, most of the large diatom cells consumed by T. brevicornis seemed to be swallowed as a whole since only a minority of frustules were broken (Fig. 3B).

A. minutus exhibited a great extent of digestion of diatom cell contents at all the diets provided (Fig. 3GI). In the other three harpacticoid species, our visual impression was that the contents of small cells was utilized less effectively than that of large cells, especially in T. brevicornis and P. fulvofasciata fed in the monoclonal cultures: essential number of small diatoms, after getting through the alimentary tract, looked almost or even completely undigested (Fig. 3A, J).

\subsection{Mouth parts' morphology}

In general, the overall body size $[T$. brevicornis (c. $850 \mu \mathrm{m})>$ P. fulvofasciata $($ c. $780 \mu \mathrm{m})>H$. obscurus (c. $550 \mu \mathrm{m})>A$. minutus $($ c. $350 \mu \mathrm{m})]$ correlates with the dimensions of the mouthparts of the harpacticoid species. T. brevicornis was characterised by the largest mouthparts, whereas the mouthparts of $A$. minutus were substantially smaller. H. obscurus was of intermediate size and so were its mouthparts. Remarkably, P. fulvofasciata has much smaller mouthparts than one would expect from its overall body size. For example, the maximum basis length (from attachment point to gnathobasis) of the mandible is $131 \mu \mathrm{m}$ in $T$. brevicornis while it measures only $48 \mu \mathrm{m}$ in P. fulvofasciata. The ratio of the mandible basis length to the total body size is 1:6 in T. brevicornis, 1:9 in A. minutus and $H$. obscurus, 1:16 in P. fulvofasciata. The ratio of the mandible basis lengths to the maximum width of the cephalothorax is $1: 3$ in $T$. brevicornis and A. minutus and 1:4 in H. obscurus and P. fulvofasciata.

Detailed observation of the mandibles of the 4 species (Fig. 4) showed rather short and compact teeth on the mandibular gnathobases (Fig. 4B, D, F, H). The labrum of T. brevicornis (arrowed in Fig. 4A) bears strong teeth where there are several stout spinules and hairs bordering the labrum of $H$. obscurus (arrowed in Fig. 4C) (both species belonging to the family Harpacticidae). The labrum of $A$. minutus (Fig. 4E) bears rather slender spinules and hairs, while it is broader in P. fulvofasciata (Fig. 4G), with stout spinules and several long hairs (both species belonging to the family Diosaccidae).

\section{Discussion}

In the present study, two of the four harpacticoid species (H. obscurus, A. minutus) showed a selectivity for the larger Seminavis cells, while P. fulvofasciata clearly preferred the smaller Seminavis cells. Based on monoclonal treatments, no clear preference was found for the largest copepod species $T$. brevicornis although there was a slight preference for large cells in the mixed treatments.

For all harpacticoid copepods, except P. fulvofasciata, the enrichment level of copepods grazing on the mixed diet dropped to half of the ${ }^{13} \mathrm{C}$ level found at monoclonal diet, suggesting that both diatom sizes contribute equally to the diet. Although $P$. fulvofasciata was the second largest species used in our experiments, it showed the highest uptake of small cells even in the mixed diet.

Consequently, our data suggest that the selected diatom size was not related to the body size of the grazer. The fact that body size seems not to be determinant for food selection is rather surprising as recent studies stress the important effect of body size (e.g. in combination with temperature) on individual metabolic rate and global C cycle (e.g. Allen et al., 2005). Moreover, the results from our case study question whether body size alone provides a useful surrogate measure of the niche of each species, and, by extension, of entire ecological networks, as was recently put forward by Woodward et al. (2005).

In general, one can distinguish between active selectivity (active choice of food components based on prey morphology or size) and passive feeding preferences (depending on differential food uptake, assimilation or digestibility) (Aberle et al., 2005). Investigations on food resource utilization by meiobenthic organisms have indicated both ingestion selectivity (e.g. Brown and Sibert, 1977; Rieper, 1978; Vanden Berghe and Bergmans, 1981; Carman and Thistle, 1985) and digestion selectivity (e.g. Decho and Castenholz, 1986) (in Decho and Fleeger, 1988). In the present study, these passive and active ways of selectivity may be linked to (1) constraints of mouthparts' morphology (passive preferences or ingestion selectivity) or (2) differences of chemical nature of the food (e.g. the extracellular polymeric substances covering the diatom frustule, associated bacteria; cfr. 'taste'; DeMott, 1988) (more active selectivity or digestion selectivity). Both points will be discussed in more detail for harpacticoid copepods.

In terms of functional morphology, Marcotte (1977) found that $T$. furcata uses its second antenna and second maxilla for initial food manipulation, the first maxilla for food movement within the oral frustum, and the mandible for crushing the particles captured. However, it is quite unlikely that the functional attributes of mouthparts as specified for T. furcata are universal for all harpacti- 
coids. The relative importance of particular oral appendages might be different between various species and also when manipulating different food items. For instance, in planktonic Calanoida, maxilles and associated filtering setae are correlated to the size of food particles (Anraku and Omori, 1963) while raptorial feeders mainly grasp particles with the maxillules (Marcotte, 1977).

Michels and Schnack-Schiel (2005) studied the importance of mandibular gnathobases for the diet of planktonic Antarctic copepod species (Calanoida). They concluded that calanoids with comparatively short and compact teeth mainly feed on diatoms as these teeth assist to crack the siliceous diatom frustules by directed pressure. From our observations, there are no major differences in mandible morphology per se between the four harpacticoid species examined. $P$. fulvofasciata had relatively smaller mandibles than one would expect from its overall body length. These morphological constraints are the primary reasons for its preference for small Seminavis cells.

In addition to its preference for smaller cells, $P$. fulvofasciata showed different assimilation abilities as several small Seminavis cells looked intact in its faecal pellets while large cells were empty. The recovery of intact small cells from faecal pellets suggests that small diatoms have a relatively short gut passage time and concomitant less time for enzymatic breakdown. Moreover, breaking of cells (as seen for larger cells) favours a more effective digestion of the cells. On the other hand, handling and uptake of larger diatom cells should be more energy-consuming than for smaller diatom cells.

Taking this inefficient assimilation of small cells into account, there must be a functional explanation for consuming a lot of small diatoms but leaving a large portion of them intact. Previous experiments indicated that the uptake of diatom cells by $P$. fulvofasciata was clearly promoted by the presence of faecal pellets while the diatom uptake by $T$. brevicornis and H. obscurus was not affected (De Troch et al., 2005). The re-use of faecal pellets seems to be advantageous for P. fulvofasciata as they consist of several intact diatom cells and probably bacteria because of microbial gardening (De Troch et al., 2005). However, these data are not entirely comparable since we used different diatom species in these experiments. The importance of bacteria for P. fulvofasciata was supported by the results of Rieper (1978) who reported that another Paramphiascella species, $P$. vararensis, grew well on a diet of solely bacteria.

In addition to associated bacteria, the extracellular polymeric substances (EPS) excreted by diatoms may be an additional food source. It is partly because of this EPS that epipelic microalgae form a microphytobenthic biofilm which is thought to play a key role in sediment biostabilisation (e.g. Underwood and Paterson, 1993; Orvain et al., 2003). Moreover, in natural environments, microalgae are associated with adherent bacteria, particularly diatoms producing an extracellular mucus rich in colourless bacteria (Buffan-Dubau et al., 1996).

From our study, we conclude that $T$. brevicornis was not size-selective as diatom grazer, while $H$. obscurus and A. minutus had a preference for large diatom cells. $P$. fulvofasciata showed a clear preference for small cells and probably this selectivity is closely linked to its microbial gardening strategy. The size selectivity of these grazers was not related to overall body size, but the maximum width of the cephalothorax seems to be a good estimator for the size of the mouthparts and related size selectivity. The cephalothorax width gives a good indication of the basis length of the mandibles, which are essential to manipulate food particles. As dissection of the mouthparts is not always evident, the width of the cephalothorax might be a good surrogate. As we demonstrated in this case study a species-specific food size selection even within one copepod family, a further generalisation towards all harpacticoid species is not appropriate. Here, we show for the first time that harpacticoid copepods are able to select between different sizes of the same diatom species.

\section{Acknowledgements}

The first author acknowledges a postdoctoral fellowship and the third author an aspirant grant, both provided by the Fund for Scientific Research (FWOFlanders, Belgium). The work was conducted within the frame of FWO research project G.0313.04. E.O. received a grant from Bijzonder onderzoeksfonds, Ghent University, during his stay in Belgium. T. Moens contributed to an interesting discussion on the interpretation of the results and M. Vincx gave valuable support to the study. Two anonymous referees gave constructive comments. [SS]

\section{References}

Aberle, N., Hillebrand, H., Grey, J., Wiltshire, K.H., 2005. Selectivity and competitive interactions between two benthic invertebrate grazers (Asellus aquaticus and Potamopyrgus antipodarum): an experimental study using ${ }^{13} \mathrm{C}$ - and ${ }^{15} \mathrm{~N}$-labelled diatoms. Freshw. Biol. 50, 369-379.

Allen, A.P., Gillooly, J.F., Brown, J.H., 2005. Linking the global carbon cycle to individual metabolism. Funct. Ecol. 19, 202-213. 
Anraku, M., Omori, M., 1963. Preliminary survey of the relationship between the feeding habitat and the structure of the mouth-parts of marine copepods. Limnol. Oceanogr. 8, 116-126.

Brown, T.J., Sibert, J.R., 1977. Food of some benthic harpactioid copepods. J. Fish. Res. Board Can. 34, 1028-1031.

Buffan-Dubau, E., Carman, K.R., 2000. Diel feeding behavior of meiofauna and their relationships with microalgal resources. Limnol. Oceanogr. 45, 381-395.

Buffan-Dubau, E., de Wit, R., Castel, J., 1996. Feeding selectivity of the harpacticoid copepod Canuella perplexa in benthic muddy environments demonstrated by HPLC analyses of chlorin and carotenoid pigments. Mar. Ecol. Prog. Ser. 137, 71-82.

Carman, K.R., Thistle, D., 1985. Microbial food partitioning by three species of benthic copepods. Mar. Biol. 88, 143-148.

Chepurnov, V.A., Mann, D.G., Vyverman, W., Sabbe, K., Danielidis, D.B., 2002. Sexual reproduction, mating system and protoplast dynamics of Seminavis (Bacillariophyta). J. Phycol. 38, 1004-1019.

Chepurnov, V.A., Mann, D.G., Sabbe, K., Vyverman, W., 2004. Experimental studies on sexual reproduction in diatoms. Int. Rev. Cyt. 237, $92-154$.

Cruz-Rivera, E., Hay, M.E., 2000. Can quantity replace quality? Food choice, compensatory feeding, and fitness of marine mesograzers. Ecology 81, 201-219.

Decho, A.W., 1988. How do harpacticoid grazing rates differ over a tidal cycle? Field verification using chlorophyll-pigment analyses. Mar. Ecol. Prog. Ser. 45, 263-270.

Decho, A.W., Castenholz, R.W., 1986. Spatial patterns and feeding of meiobenthic harpacticoid copepods in relation to resident microbial flora. Hydrobiologia 131, 87-96.

Decho, A.W., Fleeger, J.W., 1988. Ontogenetic shifts in the meiobenthic harpacticoid copepod Nitocra lacustris. Mar. Biol. 97, 191-197.

DeMott, W.R., 1988. Discrimination between algae and artificial particles by freshwater and marine copepods. Limnol. Oceanogr. 33, 397-408.

DeMott, W.R., 1989. Optimal foraging theory as a predictor of chemically mediated food selection by suspension-feeding copepods. Limnol. Oceanogr. 34, 140-154.

De Troch, M., Mees, J., Wakwabi, E.O., 1998. Diets of abundant fishes from beach seine catches in seagrass beds of a tropical bay (Gazi Bay, Kenya). Belg. J. Zool. 128, 135-154.

De Troch, M., Steinarsdóttir, M.B., Chepurnov, V., Ólafsson, E., 2005. Grazing on diatoms by harpacticoid copepods: speciesspecific density-dependent uptake and microbial gardening. Aquat. Microb. Ecol. 39, 135-144.

Fechter, A., Thistle, D., Arlt, G., Suderman, K., Vopel, K., 2004. Do harpacticoids (Copepoda) use water-born cues to aid in locating food parcels? P.S.Z.N.: Mar. Ecol. 25, 217-223.

Gee, J.M., 1989. An ecological and economic review of meiofauna as food for fish. Zool. J. Linn. Soc. 96, 243-261.

Gorokhova, E., Hansson, S., Hoglander, H., Andersen, C.M., 2005. Stable isotopes show food web changes after invasion by the predatory cladoceran Cercopagis pengoi in a Baltic Sea bay. Oecologia 143, 251-259.

Guidi, L.D., 1984. The effect of food composition on ingestion, development, and survival of a harpacticoid copepod, Tisbe cucumariae. J. Exp. Mar. Biol. Ecol. 84, 101-110.

Guillard, R.L., 1975. Culture of phytoplankton for feeding marine invertebrates. In: Smith, W.L., Chandley, M.H. (Eds.), Culture of marine invertebrate animals. Plenum Press, New York, pp. $29-60$.
Haro-Garay, M.J., 2003. Diet and functional morphology of the mandible of two planktonic amphipods from the Strait of Georgia, British Columbia, Parathemisto pacifica (Stebbing, 1888) and Cyphocaris challengeri (Stebbing, 1888). Crustaceana 76, $1291-1312$.

Hicks, G.R.F., Coull, B.C., 1983. The ecology of marine meiobenthic harpacticoid copepods. Oceanogr. Mar. Biol.: Ann. Rev. 21, 67-175.

Hillebrand, H., Dürselen, C.-D., Kirschtel, D., Pollingher, U., Zohary, T., 1999. Biovolume calculation for pelagic and benthic microalgae. J. Phycol. 35, 403-424.

Irigoien, X., Head, R.N., Harris, R.P., Cummings, D., Harbour, D., Meyer-Harms, B., 2000. Feeding selectivity and egg production of Calanus helgolandicus in the English Channel. Limnol. Oceanogr. 45, 44-54.

Kiorboe, T., Saiz, E., Viitasalo, M., 1996. Prey switching behaviour in the planktonic copepod Acartia tonsa. Mar. Ecol. Prog. Ser. 143, $65-75$.

Lopez, G.W., 1982. Short-term population dynamics of Tisbe cucumariae (Copepoda: Harpacticoida). Mar. Biol. 68, 333-341.

Marcotte, B.M., 1977. An introduction to the architecture and kinematics of harpacticoid (Copepoda) feeding: Tisbe furcata (Baird, 1837). Mikrofauna Meeresbod. 61, 183-196.

Michels, J., Schnack-Schiel, S.B., 2005. Feeding in dominant Antarctic copepods - does the morphology of the mandibular gnathobases relate to diet? Mar. Biol. 146, 483-495.

Middelburg, J.J., Barranguet, C., Boschker, H.T.S., Herman, P.T., Moens, T., Heip, C.H.R., 2000. The fate of intertidal microphytobenthos carbon: an in situ ${ }^{13} \mathrm{C}$-labeling study. Limnol. Oceanogr. $45,1224-1234$.

Moore, J., 1975. The role of algae in the diet of Asellus aquaticus and Gammarus pulex. J. Anim. Ecol. 44, 719-730.

Orvain, F., Galois, R., Barnard, C., Sylvestre, A., Blanchard, G., Sauriau, P.G., 2003. Carbohydrate production in relation to microphytobenthic biofilm. Microb. Ecol. 45, 237-251.

Pace, M.C., Carman, K.R., 1996. Interspecific differences among meiobenthic copepods in the use of microalgal food sources. Mar. Ecol. Prog. Ser. 143, 77-86.

Porter, K.G., 1973. Selective grazing and differential digestion of algae by zooplankton. Nature $244,179-180$.

Rieper, M., 1978. Bacteria as food for marine harpacticoid copepods. Mar. Biol. 45, 337-345.

Rieper, M., 1982. Feeding preferences of marine harpacticoid copepods for various species of bacteria. Mar. Ecol. Prog. Ser. 7, 303-307.

Rieper, M., 1985. Some lower food web organisms in the nutrition of marine harpacticoid copepods: an experimental study. Helgol. Meeresunters. 39, 357-366.

Rieper, M., Flotow, C., 1981. Feeding experiments with bacteria, cliates and harpacticoid copepods. Kiel. Meeresforsch. 39, $370-375$.

Rieper-Kirchner, M., Hinz, K., Biddanda, B., 1991. Ingestion of microbially-synthesized organic aggregates and egestion of fecal pellets by marine harpacticoid copepods. Kiel. Meeresforsch. 8, 257-263.

Rudnick, D.T., 1989. Time lags between the deposition and meiobenthic assimilation of phytodetritus. Mar. Ecol. Prog. Ser. 50, 231-240.

Seifried, S., Durbaum, J., 2000. First clear case of carnivory in marine Copepoda (Harpacticoida). J. Nat. Hist. 34, 1595-1618.

Sogard, S.M., 1984. Utilization of meiofauna as a food source by a grassbed fish, the spotted dragonet Callionymus pauciradiatus. Mar. Ecol. Prog. Ser. 17, 183-191. 
Sommer, F., Stibor, H., Sommer, U., Velimirov, B., 2000. Grazing by mesozooplankton from Kiel Bight, Baltic Sea, on different sized algae and natural seston size fractions. Mar. Ecol. Prog. Ser. 199, $43-53$.

StatSoft, Inc., 2001. STATISTICA (data analysis software system), version 6. www.statsoft.com.

Stephens, D.W., Krebs, J.R., 1986. Foraging Theory. University Press, Princeton, NJ.

Tackx, M.L.M., Herman, P.J.M., Gasparini, S., Irigoien, X., Billiones, R., Daro, M.H., 2003. Selective feeding of Eurytemora affinis (Copepoda, Calanoida) in temperate estuaries: model and field observations. Estuar. Coast. Shelf Sci. 56, 305-311.

Turner, J.T., 2004. The importance of small planktonic copepods and their roles in pelagic marine food webs. Zool. Stud. 43, 255-266.
Underwood, G.J.C., Paterson, D.M., 1993. Seasonal changes in diatom biomass, sediment stability and biogenic stabilization in the Severn Estuary. J. Mar. Biol. Assoc. U.K. 73, 871-887.

Underwood, G.J.C., Thomas, J.D., 1990. Grazing interactions between pulmonate snails and epiphytic algae and bacteria. Freshw. Biol. 23, 505-522.

Vanden Berghe, W., Bergmans, M., 1981. Differential food preferences in three co-occurring species of Tisbe (Copepoda Harpacticoida). Mar. Ecol. Prog. Ser. 4, 213-219.

Woodward, G., Ebenman, B., Emmerson, M., Montoya, J.M., Olesen, J.M., Valido, A., Warren, P.H., 2005. Body size in ecological networks. Trends Ecol. Evol. 20, 402-409. 